\title{
Role of gallium 67 thoracic scintigraphy in the diagnosis and staging of patients suspected of bronchial carcinoma
}

\author{
R PANNIER, I VERLINDE, I PUSPOWIDJONO, JP WILLEMOT \\ From the Department of Pneumology, AZ St Jan Brugge, Belgium
}

ABSTRACT Gallium $67\left({ }^{67} \mathrm{Ga}\right)$ lung scanning was performed in 100 consecutive cases in which because of the history, clinical data, or abnormal radiological findings, a bronchial carcinoma was $\stackrel{\perp}{\perp}$ suspected. This study allows the conclusion that a negative as well as a positive scan is an important $\mathrm{O}$ element in the diagnosis of some cases of broncial carcinoma. The method is most helpful in the $\rightarrow$ preoperative diagnosis of circumscribed peripheral shadows and in the assessment of suspected hilar $\frac{\vec{D}}{0}$ enlargement; it may even visualise hidden malignant tumours. Gallium 67 scanning is also valuable in the assessment of hilar and mediastinal involvement in the presence of a proven primary lung $\vec{\oplus}$ tumour. This study supports the view that in the presence of a negative mediastinal scan the patient ? may be spared mediastinoscopy and be referred directly for operation.

Gallium $67\left({ }^{67} \mathrm{Ga}\right)$ scintigraphy was first introduced into clinical practice by Edwards and Hayes. ${ }^{1}$ There is now fairly general agreement that ${ }^{67} \mathrm{Ga}$ accumulation occurs in a high percentage of cases of carcinoma of the lung, but also in inflammatory lesions of the bacterial type (acute pneumonia, acute lung abscess, acute tuberculosis) and in active granulomatous pulmonary disease (sarcoid, pneumoconiosis). Thus this isotope cannot be used as a specific tumour tracing agent. The rate of positivity of the ${ }^{67} \mathrm{Ga}$ lung scintigram is also low in inactive lung disorders and non-malignant tumours. ${ }^{2}$

However, experience shows that there are circumstances in which the ${ }^{67} \mathrm{Ga}$ chest scintigram is a valuable additional investigation in the approach to the diagnosis of bronchial carcinoma, and in the preoperative staging of the patients. The present study concerns the more specific role of ${ }^{67} \mathrm{Ga}$ lung and mediastinal scintigraphy in the diagnosis and preoperative assessment of bronchial carcinoma.

\section{Patients and methods}

We reviewed 100 consecutive cases in which the history, clinical data, or abnormal radiological findings supported a potential diagnosis of bronchial carcinoma.

Thoracic scintigraphy was performed 48 hours

Address for reprint requests: Dr R Pannier, 8000 Brugge, Augustijnenrei 7, Belgium. after the intravenous administration of $2-3 \mathrm{mCi}$ of gallium 67 citrate; a Pho-Gamma HP Gamma $\stackrel{\odot}{\Phi}$ camera was used.

Posterior, anterior and lateral scintigrams were obtained. The images were interpreted by two different persons without knowledge of the radiographs. They were recorded as positive when the uptake was undoubtedly higher than that of the surrounding tissues, doubtful when the contrast was less marked, and negative when no uptake could be seen.

As MacLeod ${ }^{3}$ had already pointed out, the midmediastinal region may be difficult to assess because the radioactivity of ${ }^{67} \mathrm{Ga}$ in the marrow of theo vertebrae and the sternum interferes. In all the 100 cases studied the final diagnosis was confirmed byo the clinical and radiological evolution, results of bacteriology, and the histo- or cyto-pathologicalo findings. There were 65 primary carcinomas of theN lung.

\section{Results}

A POSitive AS WELl AS A NEGATIVE ${ }^{67}$ GA SCINTIGRAM IS IMPORTANT DIAGNOSTICALLY

In the 100 cases with a radiological or clinica suspicion of bronchial carcinoma, ${ }^{67} \mathrm{Ga}$ thoracie्ष户 scintigraphy was positive in 69 , doubtful in nine, an ${ }^{2}$ negative in 22 cases (table 1 ). The high percentage of carcinoma in this series was the result of selection, as 
Table 1 Results of ${ }^{67} \mathrm{Ga}$ thoracic scintigraphy in 100 cases suspected of primary bronchial carcinoma

\begin{tabular}{|c|c|c|c|c|}
\hline \multirow[t]{2}{*}{ Main radiographic or clinical signs } & \multirow[t]{2}{*}{$n$} & \multicolumn{3}{|c|}{ Lung ${ }^{67} \mathrm{Ga}$ scan } \\
\hline & & Positive & Dubious & Negative \\
\hline $\begin{array}{l}\text { Lung infiltration } \\
\text { Circumscribed round shadow }<4 \mathrm{~cm} \\
\text { Circumscribed round shadow }>4 \mathrm{~cm} \\
\text { Suspect hilar enlargement } \\
\text { Chronic bronchitis with or without haemoptysis normal radiography } \\
\text { Total }\end{array}$ & $\begin{array}{r}57 \\
9 \\
12 \\
12 \\
10 \\
100\end{array}$ & $\begin{array}{r}43 \\
4 \\
12 \\
9 \\
1 \\
69\end{array}$ & $\begin{array}{l}6 \\
2 \\
0 \\
1 \\
0 \\
9\end{array}$ & $\begin{array}{r}8 \\
3 \\
0 \\
2 \\
9 \\
22\end{array}$ \\
\hline
\end{tabular}

most of the acute inflammatory diseases had been ruled out on clinical grounds or on radiological evidence. On the basis of the radiological findings, or, in the absence of an abnormal radiological picture, of the most important clinical data, the whole series was subdivided into five groups: (1) lung infiltration with or without enlarged lymph nodes; $(2)$ circumscribed densities less than $4 \mathrm{~cm}$ in diameter; (3) circumscribed densities larger than $4 \mathrm{~cm}$ in diameter; (4) suspected abnormal hilar shadows; (5) chronic bronchitis in heavy smokers with deterioration of the general condition and loss of weight with or without haemoptysis.

Table 1 summarises the results of ${ }^{67} \mathrm{Ga}$ scintigraphy in the 100 patients suspected of bronchial carcinoma. Of the 69 cases with a positive thoracic ${ }^{67} \mathrm{Ga}$ scintigram, 59 had a bronchial carcinoma confirmed later, eight had a pulmonary infection, and two had pulmonary tuberculosis (table 2). Of the nine cases with a doubtful ${ }^{67} \mathrm{Ga}$ scintigram, six had a bronchial carcinoma, two pulmonary infection, and one bronchitis (table 3 ). Of the 22 cases with a negative ${ }^{67} \mathrm{Ga}$ scintigram, one had an adenocarcinoma confirmed later, one a benign tumour, seven pneumonic infiltration, one pulmonary sarcoidosis, one lung infarction, and two chronic bronchitis (table 4).

This study shows that all but one of the 66 cases with bronchial carcinoma (tables 2-4) had a positive (59) or dubious (six) ${ }^{67} \mathrm{Ga}$ scintigram and what is more important, that of the 22 cases with a negative scintigram only one was found at operation to have a carcinoma (table 5). Of the 66 cases with bronchial carcinoma the rate of positive, dubious and negative scintigraphy was in our series respectively $89.4 \%$, $9.1 \%$, and $1.5 \%$. Data collected from 20 published papers show that when subdivided into positive and negative scintigrams, the results were respectively $89 \%$ and $11 \%$ and when separated into positive,

Table 2 Final diagnosis in 69 cases with positive ${ }^{67} \mathrm{Ga}$ thoracic scintigram

\begin{tabular}{|c|c|c|c|c|}
\hline Main radiographic or clinical signs & $n$ & Carcinoma & Pneumoritis & Tuberculosis \\
\hline Lung infiltration & 43 & 34 & 8 & 1 \\
\hline Circumscribed round shadow $<4 \mathrm{~cm}$ & 4 & 4 & 一 & - \\
\hline Circumscribed round shadow $>4 \mathrm{~cm}$ & 12 & 11 & 一 & 1 \\
\hline Suspect hilar enlargement & 9 & 9 & - & - \\
\hline Chronic bronchitis with or without haemoptysis normal radiography & 1 & 1 & 一 & - \\
\hline Total & 69 & 59 & 8 & 2 \\
\hline
\end{tabular}

Table 3 Final diagnosis in nine cases with dubious ${ }^{67} \mathrm{Ga}$ thoracic scintigram

\begin{tabular}{lcccc}
\hline Main radiographic or clinical signs & $n$ & Carcinoma & Pneumonitis & Bronchitis \\
\hline Lung infiltration & 6 & 3 & 2 & 1 \\
Circumscribed round shadow $<4 \mathrm{~cm}$ & 2 & 2 & - & - \\
Circumscribed round shadow $>4 \mathrm{~cm}$ & 0 & - & - \\
Suspect hilar enlargement & 1 & 1 & - & - \\
Chronic bronchitis with or without haemoptysis normal radiography & - & 6 & 2 & 1 \\
Total & 9 & - & - \\
\hline
\end{tabular}

Table 4 Final diagnosis in 22 cases with negative ${ }^{67} \mathrm{Ga}$ thoracic scintigram

\begin{tabular}{|c|c|c|c|c|c|c|c|}
\hline Main radiographic or clinical signs & $n$ & Carcinoma & $\begin{array}{l}\text { Benign } \\
\text { tumour }\end{array}$ & $\begin{array}{l}\text { Pneumonic } \\
\text { infiltration }\end{array}$ & Sarcoidosis & Infarct & Bronchitis \\
\hline Lung infiltration & 8 & - & - & 7 & 1 & - & - \\
\hline Circumscribed round shadow $<4 \mathrm{~cm}$ & 3 & 1 & 1 & - & - & 1 & - \\
\hline Circumscribed round shadow $>4 \mathrm{~cm}$ & 0 & 一 & - & - & - & - & - \\
\hline Suspect hilar enlargement & 2 & 一 & - & - & - & - & 2 \\
\hline Chronic bronchitis with or without & & & & & & & \\
\hline $\begin{array}{l}\text { haemoptysis normal radiography } \\
\text { Total }\end{array}$ & $\begin{array}{r}9 \\
22\end{array}$ & - & $\overline{1}$ & $\overline{7}$ & $\overline{1}$ & -1 & 9 \\
\hline
\end{tabular}


Table 5 Results of ${ }^{67} \mathrm{Ga}$ thoracic scintigraphy in 66 cases of bronchial carcinoma

\begin{tabular}{|c|c|c|c|c|c|c|c|}
\hline & \multirow[t]{2}{*}{$n$} & \multicolumn{6}{|c|}{${ }^{67} \mathrm{G} a$ thoracic scint igraphy } \\
\hline & & Positive & $\%$ & Dubious & $\%$ & Negative & $\%$ \\
\hline Bronchial carcinoma & 66 & 59 & $89 \cdot 4$ & 6 & $9 \cdot 1$ & 1 & $1 \cdot 5$ \\
\hline
\end{tabular}

dubious, and negative, respectively $86 \%, 6 \%$, and $8 \%$ (table 6 a-b).

The value of slightly positive scintigraphy is still a matter of discussion. Our findings support Cellerino's ${ }^{18}$ view that the recording of dubious scintigrams is worthwhile since in our own series a high proportion (six out of nine) proved later on to be neoplasms.

We also conclude that as far as primary carcinoma is concerned false positive and false negative scintigrams are rare. We support Siemsen's ${ }^{22}$ opinion that one should refrain from a classification into "true positive", "false negative" and so on. We previously pointed out that one should always add to the result of the scintigram the disease concerned. ${ }^{23}$ On this basis the result of ${ }^{67} \mathrm{Ga}$ thoracic scintigraphy along with radiology permits an improved level of diagnosis. It allows one to rule out or postpone more invasive investigations in negative cases, or in positive cases to accept carcinoma as the cause. In elderly patients with a clinical and radiological picture suggestive of carcinoma and where more invasive techniques should be avoided, a positive chest scintigram adds an important element in back- $\vec{x}$ ing up the diagnosis, and a negative one in ruling it out.

GALLIUM 67 SCINTIGRAPHY IS MOST

HELPFUL IN THE DIAGNOSTIC EVALUATION OF CIRCUMSCRIBED PERIPHERAL SHADOWS AND "COIN" LESIONS

Because of their peripheral situation the diagnostic evaluation of round shadows causes a special $\vec{\oplus}$ difficulty. For the clinician it is most important to know from the first if the lung abnormality has a high chance of being malignant or not. In the present study there were nine cases with a round circumscribed shadow less than $4 \mathrm{~cm}$ in diameter; four

Table 6 Collected results from 20 papers on ${ }^{67} \mathrm{Ga}$ scanning in broncial carcinoma

(a) Scans classified as positive or negative

\begin{tabular}{|c|c|c|c|c|c|c|}
\hline \multirow[t]{3}{*}{ Authors } & \multirow[t]{3}{*}{ Year } & \multicolumn{5}{|c|}{${ }^{B 2}$ Ga scan } \\
\hline & & \multirow[t]{2}{*}{ Total } & \multicolumn{2}{|c|}{ Positive } & \multicolumn{2}{|c|}{ Negative } \\
\hline & & & $n$ & $\%$ & $n$ & $\%$ \\
\hline Edwards and Hayes ${ }^{1}$ & 1970 & 7 & 5 & 71 & 2 & 29 \\
\hline Hisada and Hiraki ${ }^{4}$ & 1970 & 19 & 19 & 100 & $\overline{0}$ & 0 \\
\hline Hör et $a l^{5}$ & 1970 & 30 & 27 & 90 & 3 & 10 \\
\hline Ito $e^{2} a^{16}$ & 1971 & 21 & 21 & 100 & 0 & 0 \\
\hline Fogh and Edeling ${ }^{6}$ & 1972 & 73 & 70 & 96 & 3 & 4 \\
\hline Van der Schoot? & 1972 & 85 & 78 & 92 & 7 & 6 \\
\hline Langhammer et $a l^{8}$ & 1972 & 62 & 56 & 90 & 6 & 10 \\
\hline Guérin et $a l^{9}$ & 1973 & 29 & 20 & 68 & 9 & 32 \\
\hline Frölich et $a l^{10}$ & 1973 & 105 & 96 & 91 & 9 & 9 \\
\hline Blasi et al ${ }^{11}$ & 1974 & 109 & 96 & 97 & 4 & 3 \\
\hline Perrin Fayolle et $a l^{12}$ & 1975 & 35 & 16 & 46 & 19 & 54 \\
\hline Demeester et al $^{13}$ & 1977 & 47 & 44 & 94 & 3 & 6 \\
\hline Alazraki et al ${ }^{14}$ & 1978 & 31 & 25 & 81 & 6 & 19 \\
\hline Siemsen et $a l^{22}$ & 1978 & 264 & 237 & 90 & 27 & 10 \\
\hline \multirow{2}{*}{ Fosburg et al ${ }^{15}$} & 1979 & 75 & 70 & 93 & 5 & 7 \\
\hline & & 992 & 880 & 89 & 103 & 11 \\
\hline
\end{tabular}

(b) Scans classified as positive, dubious, negative

\begin{tabular}{|c|c|c|c|c|c|c|c|c|}
\hline \multirow[t]{3}{*}{ Authors } & \multirow[t]{3}{*}{ Year } & \multicolumn{7}{|c|}{${ }^{67} \mathrm{Ga}$ scan } \\
\hline & & \multirow[t]{2}{*}{ Total } & \multicolumn{2}{|c|}{ Positive } & \multicolumn{2}{|c|}{ Dubious } & \multicolumn{2}{|c|}{ Negative } \\
\hline & & & $n$ & $\%$ & $n$ & $\%$ & $n$ & $\%$ \\
\hline $\begin{array}{l}\text { Higasi et } a l^{17} \\
\text { Cellerino et al }{ }^{18} \\
\text { Kinoshita } \text { et } a l^{18} \\
\text { Deland } \text { et } a l^{20} \\
\text { Pinsky and Henkin }{ }^{21}\end{array}$ & $\begin{array}{l}1972 \\
1973 \\
1974 \\
1975 \\
1976\end{array}$ & $\begin{array}{r}19 \\
32 \\
70 \\
172 \\
172 \\
465\end{array}$ & $\begin{array}{r}18 \\
27 \\
62 \\
146 \\
145 \\
398\end{array}$ & $\begin{array}{l}95 \\
85 \\
89 \\
85 \\
84 \\
86\end{array}$ & $\begin{array}{r}0 \\
3 \\
7 \\
10 \\
10 \\
30\end{array}$ & $\begin{array}{r}0 \\
9 \\
10 \\
6 \\
6 \\
6\end{array}$ & $\begin{array}{r}1 \\
2 \\
1 \\
17 \\
17 \\
37\end{array}$ & $\begin{array}{r}5 \\
6 \\
1 \\
10 \\
10 \\
8\end{array}$ \\
\hline
\end{tabular}


showed a positive ${ }^{67} \mathrm{Ga}$ chest scintigram (table 1 ), two a dubious scintigram, and in three cases the image was negative. All but one of the positive or doubtful cases proved later to be malignant. In the three negative cases the final diagnosis was one benign tumour, one lung infarction, and one adenocarcinoma (the size of the tumour was $3 \mathrm{~cm}$ ). When the peripheral tumour was more than $4 \mathrm{~cm}$ in diameter 11 of the 12 patients with positive ${ }^{67} \mathrm{Ga}$ lung scintigrams had carcinomas (table 2) and one a tuberculoma (table 4). No dubious or negative scintigrams were found in our series (tables 3 and 4).

Our study confirms Cellerino's ${ }^{18}$ experience. In a series of 50 consecutive cases of peripheral lung shadow, he found malignant neoplasms in 35 of 41 positive scintigrams $(84 \%)$ the other cases being asbestosis (one), abscesses (three), and chronic infections (two). On the other hand, all but two of the nine patients with negative ${ }^{67} \mathrm{Ga}$ scintigrams had non-malignant disease. One of the two patients with false negative scintigrams had a tumour smaller than $2 \mathrm{~cm}$ and the other had been treated with cytostatic drugs just before the scintigraphy. Most authors 210182022 now agree that tumours smaller than $2 \mathrm{~cm}$ are not identifiable on a ${ }^{67} \mathrm{Ga}$ chest scintigram.

One of our patients with a peripheral round shadow and negative scan was suffering from pulmonary infarction. The shadow disappeared shortly after treatment with anticoagulant drugs. Siemsen et $a l^{22}$ and Niden et $a l^{24}$ have drawn attention to the fact that as a rule pulmonary infarctions are Gallium negative, with the exception of septic emboli associated with endocarditis. Thus ${ }^{67} \mathrm{Ga}$ chest scintigrams may be of value in the differential diagnosis of pulmonary infarction and pneumonitis.

All these findings suggest that in the presence of peripheral round lung shadows larger than $2 \mathrm{~cm}$ and not previously treated with antimitotic drugs or irradiation, a negative ${ }^{67} \mathrm{Ga}$ chest scintigram nearly always excludes malignancy, while positive ${ }^{67} \mathrm{Ga}$ scintigrams establish a high probability of the malignant nature of the lesion.

\section{GALLIUM 67 THORACIC SCINTIGRAPHY IS VALUABLE IN THE ASSESSMENT OF \\ ABNORMAL HILAR SHADOWS}

Another situation in which ${ }^{67} \mathrm{Ga}$ scintigrams may be helpful in assessing the presence or absence of disease, concerns abnormal hilar shadows. In our series of 12 patients in this category with positive or dubious scintigrams, 10 turned out to have carcinoma (tables 2,3 ) and two bronchitis (table 4). The ${ }^{67} \mathrm{Ga}$ scintigram is helpful in distinguishing enlarged hilar blood vessels and inactive granulomatous disease in enlarged lymph nodes, in which case the scintigram is negative, from neoplastic or active granulomatous disease where an accumulation of the isotope will be seen on the scintigram.

\section{GALLIUM 67 SCINTIGRAPHY MAY DISCLOSE}

HIDDEN MALIGNANT TUMOURS

In 10 of the cases studied in this series (tables 2, 4) ${ }^{67} \mathrm{Ga}$ chest scintigraphy was performed in patients where chronic bronchitis and loss of weight or haemoptysis suggested the possibility of a malignant process in the lung, in the absence of any radiographic evidence. To our surprise in one such case the chest scintigram was positive (figure) and suggested the presence of bronchial carcinoma located in the retro-hilar region. In this case both bronchoscopy and bronchography were negative at the time, but subsequently histological evidence of malignancy was obtained. Fosburg ${ }^{15}$ was also impressed by the ability of ${ }^{67} \mathrm{Ga}$ to detect unsuspected foci hidden behind the heart shadow. Siemsen ${ }^{22}$ pointed out that the scintigram can also visualise tumours beneath the shadow of the cupola of the diaphragm. Although our own experience is limited it seems that ${ }^{67} \mathrm{Ga}$ thoracic scintigraphy might be useful in patients clinically suspected of bronchial carcinoma in the absence of any radiological evidence.

GALLIUM 67 THORACIC SCINTIGRAPHY IS

HELPFUL IN THE ASSESSMENT OF HILAR AND

MEDIASTINAL INVOLVEMENT IN THE

PRESENCE OF A PROVEN PRIMARY LUNG

TUMOUR

Since ${ }^{67} \mathrm{Ga}$ has a great affinity for malignant tumour cells it was logical to see if the isotope could be of help in assessing the mediastinum in the presence of a proven primary malignancy in the lung. Radiographic and tomographic studies often fail to reveal such involvement, and mediastinoscopy is an invasive procedure.

The results of ${ }^{67} \mathrm{Ga}$ mediastinal scintigraphy in the detection of metastatic involvement are shown in table 7 . In all 11 cases with a negative mediastinal scintigram the lymph node specimens were free of tumour; of the seven doubtful cases four showed a histological picture of anthracosis, and two had metastatic involvement by a squamous cell carcinoma.

Demeester et al, ${ }^{13}$ Alazraki et al, ${ }^{17}$ and Peters et $a l^{26}$ suggest that the ${ }^{67} \mathrm{Ga}$ scintigram is useful in determining the need for mediastinoscopy. All these studies showed that the ${ }^{67} \mathrm{Ga}$ scintigram was mostly positive in surgically proven mediastinal or hilar enlargement $-84 \%$ of the series of Alazraki et al ${ }^{14}$; 18 out of 19 patients in Julian et al ${ }^{25}$ whose single false negative $\mathrm{Ga}$ case had only small microscopic 


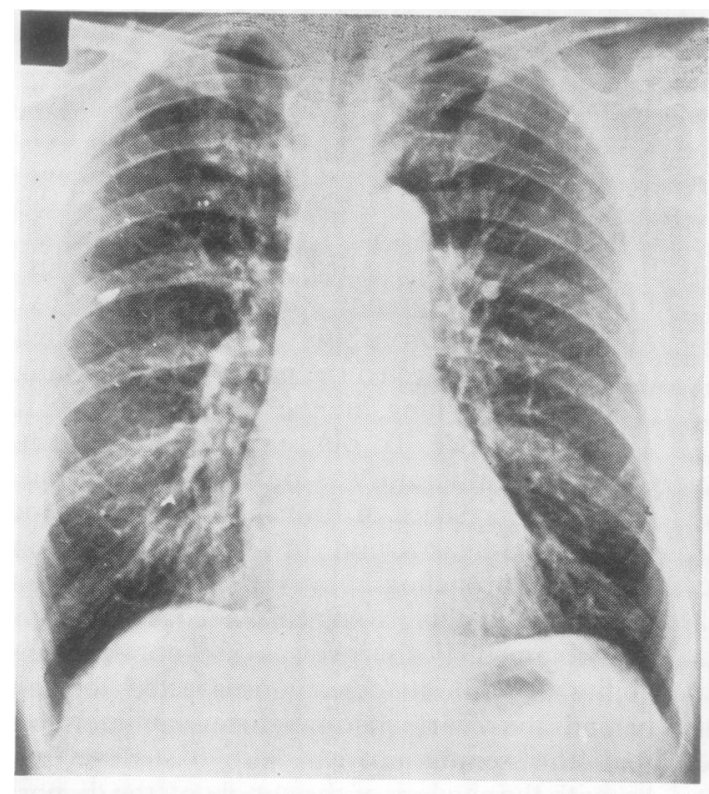

(a)

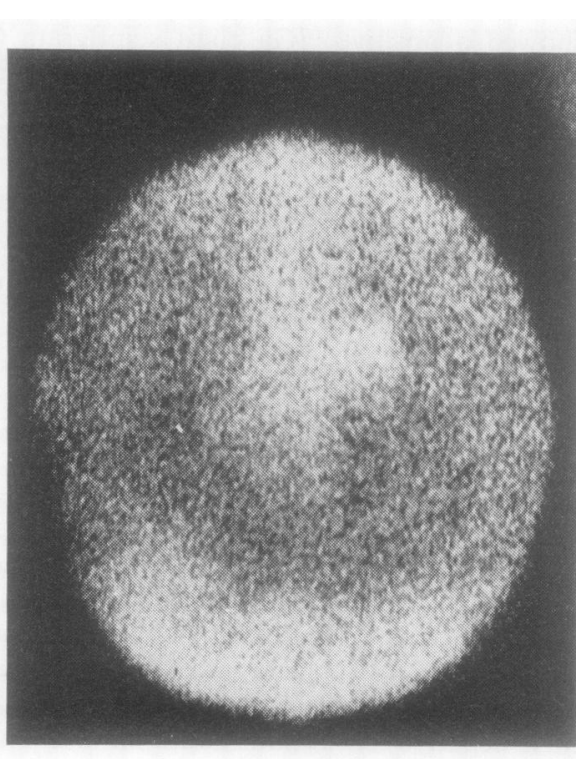

(b)

Figure (a) Normal chest radiograph in presence of haemoptysis. (b) ${ }^{67} \mathrm{G}$ a scintigram demonstrating a positive uptake in the left hilar region. Anterior-posterior view.

Table 7 Comparison between the results of ${ }^{67} \mathrm{Ga}$ mediastinal scintigraphy and lymph node histology

\begin{tabular}{ll}
\hline "Ga mediastinal scintigraphy & Lymph node histology \\
\hline Positive 1 & Metastatic involvement 1 \\
Dubious 7 & Metastatic involvement 2 \\
& Negative 1 \\
Negative 11 & Anthracosis 4 \\
\hline
\end{tabular}

foci involving the hilar lymph nodes. Demeester et $a l^{13}$ found a normal scintigram to be accurate in $76 \%$ of their cases. These authors concluded that ${ }^{67} \mathrm{Ga}$ scintigraphy is competitive with mediastinoscopy, while Alazraki et al, ${ }^{14}$ who reported on the degree of correlation between radiographic techniques, mediastinoscopy, and ${ }^{67} \mathrm{Ga}$ scintigraphy found a higher true positive ratio for ${ }^{67} \mathrm{Ga}$ scintigraphy than for chest radiography. The results of our study support Alazraki's ${ }^{14}$ and Peters' ${ }^{26}$ view, that when a proven primary carcinoma is present in the lung and the ${ }^{67} \mathrm{Ga}$ scan of the mediastinum is negative, the patient may be spared a mediastinoscopy and be referred directly for thoracotomy.

In 15 recent cases in which we followed this policy, the results were encouraging as none of them showed mediastinal spread at operation. On the other hand in patients with a positive or doubtful concentration of ${ }^{67} \mathrm{Ga}$ in the mediastinum mediastinoscopy is indicated in order to differentiate between metastatic invasion and active inflammatory nodes.
The accuracy of ${ }^{67} \mathrm{Ga}$ in revealing metastatic involvement in the mediastinum leads us to sugges that sequential ${ }^{67} \mathrm{Ga}$ scanning may contribute usefug information in the assessment of the mediastinum in the postoperative follow-up.

\section{Conclusion}

Gallium thoracic scintigraphy is not a definitive procedure in the differential diagnosis of lung cancer. and other active lung disorders. However a negative scan separates lung disorders associated with high cellular proliferation or high metabolic activity from? more benign or inactive disease, and has the advan $\frac{D}{8}$ tage of being non-invasive. Where primary bronchiale. carcinoma is suspected a negative scintigram usually excludes malignancy, so that in practice a negative scintigram is of greater value than a positive one. N Because of the rather high cost, ${ }^{67} \mathrm{Ga}$ scanning cannot $\omega$ be included as a routine procedure in all clinicato investigations. It must be reserved for those caseş where previous clinical assessment suggests the presence of a carcinoma. In these cases it will provideuseful extra information.

\section{References}

${ }^{1}$ Edwards CL, Hayes RL. Tumor scanning with $67 \mathrm{Ga}-\frac{\mathrm{O}}{\mathrm{O}}$ citrate. J Nucl Med 1969;10:103-5.

${ }^{2}$ Siemsen JK, Grebe SF, Sargent EN, Wentz D. Gallium-67尺 scintigraphy of pulmonary diseases as a complement tor

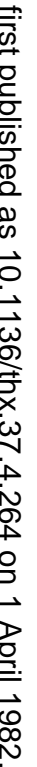

¿ 
radiography. Radiology 1976;118:371-5.

${ }^{3}$ MacLeod WM. 67 Gallium scan in diagnosis of bronchial carcinoma. Thorax 1972;27:507.

${ }^{4}$ Hisada T, Hiraki T. Limit and significance of $67 \mathrm{Ga}$ for diagnosis of malignant tumors. Igaku no Ayumi 1970;72: 590-2.

- Hör G, Glaubitt G, Grebe SF et al. Tumorscintigraphie mit 67 Ga. Presented at 8th Annual Meeting; Society of Nuclear Medicine, Sept 1970, Hanover, Germany.

- Fogh J, Edeling CJ. $67 \mathrm{Ga}$ scintigraphy of malignant tumors. Nucl Med 1972;11:371-95.

? Van der Schoot JB, Van Marle-Van der Goot M, Groen AS, de Jong J. Gallium 67 scintigraphy in benign lung disease. In: Medical Radioisotope Scintigraphy 1972. Proceedings of a Symposium. Vienna: International Atomic Energy Agency, 1973.

${ }^{8}$ Langhammer H, Glaubitt G, Grebe SF et al. $67 \mathrm{Ga}$ for tumor scanning. J Nusl Med 1975;16:25-30.

${ }^{9}$ Guérin RA, Heintz $\mathrm{CH}$, Sors $\mathrm{CH}$. Diagnostic des tumeurs malignes intra-thoraciques par scintigraphie au GA 67. Nouv Presse Méd 1973;2:981-6.

${ }^{10}$ Fröhlich G, Inoue Y, Magnus E. Significance of $67 \mathrm{Ga}-$ citrate application for diagnosis of thoracic tumors. Fortschr Geb Roentgenstr Nuklar Med 1973;119:578-87.

${ }^{11}$ Blasi A, Carratu L, Salvatore M, Sonaglioni F, Jeanty JP. Les indicateurs positif dans le diagnostic scintigraphique en pneumologie. Poumon Coeur 1974;30:225-41.

12 Perrin-Fayolle M, Brun J, Moret R, Kofman J, Ortonne $J P$, Petigny C. Etude critique de la scintigraphie au Gallium 67 en pathologie respiratoire. Rev Fr Mal Respir $1975 ; 3$, suppl $1: 193-202$.

${ }^{13}$ De Meester TR, Bekerman C, Joseph JG et al. Gallium 67 scanning for carcinoma of the lung. $J$ Thorac Cardiovasc Surg 1976;72:699-708.

${ }^{14}$ Alazraki NP, Ramsdell JW, Taylor A, Friedman PJ, Peters RM, Tisi GM. Reliability of Gallium scan chest radiography compared to mediastinoscopy for evaluating mediastinal spread in lung cancer. Am Rev Respir Dis $1978 ; 117: 415-20$.
${ }^{15}$ Fosburg RG, Hopkins GB, Kan MK. Evaluation of the mediastinum by $67 \mathrm{Ga}$ scintigraphy in lung cancer. $J$ Thorac Cardiovasc Surg 1979;77:76-82.

${ }^{16}$ Ito Y, Okuyama S, Awano T, Takahashi K, Sato T, Kanno I. Diagnostic evaluation of $67 \mathrm{Ga}$ scanning of lung cancer and other diseases. Radiology 1971;101: 355-62.

17 Higasi T, Nakayama Y, Murata A et al. Clinical evaluation of 67 Ga-citrate scanning. J Nucl Med 1972;13:196-201.

${ }^{18}$ Cellerino A, Filippi PG, Chiantaretto A, Borasio P. Operative and pathologic survey of 50 cases of peripheral lung tumors scanned with 67 Gallium. Chest 1973;64: $700-5$.

${ }^{19}$ Kinoshita F, Ushio T, Maekawa A, Ariwa R, Kubo A. Scintiscanning of pulmonary diseases, with $67 \mathrm{Ga}$ citrate. J Nucl Med 1974;15:227-33.

${ }^{20}$ Deland FH, Sauerbrunn BJL, Boyd C et al. 67 Ga-citrate imaging in untreated primary lung cancer: preliminary report of cooperative group. $J$ Nucl Med $1974 ; 15: 408-11$.

${ }^{21}$ Pinsky SM, Henkin RE. Gallium 67-tumor scanning. Semin Nucl Med 1976;6:397-409.

${ }^{22}$ Siemsen JK, Grebe SF, Waxman AD. The use of Gallium67 in pulmonary disorders. Semin Nucl Med 1978;8:23549.

${ }^{23}$ Pannier R, Verlinde I, Puspowidjono I, Willemot JP, De Pondt. Value of Gallium-67 scan in the evaluation of mediastinal involvement in lung cancer. Acta Tuberc Pneumol Belg 1979;70:353-62.

${ }^{24}$ Niden AH, Mishkin FS, Khurana MM, Pink R. 67 Gallium lung scan. An aid in the differential diagnosis of pulmonary embolism and pneumonitis. JAMA 1977; 237:1206-11.

${ }^{25}$ Julian P, Waxman AD, Komaiko M. Role of the chest $X$-ray, linear tomography and Gallium 67 radionuclide examination in staging of chest tumors. Presented at the 63rd Annual Meeting of the Radiological Society of North America, November 1977.

${ }^{26}$ Peters RM. See discussion of paper by De Meester TR et al. $J$ Thorac Cardiovasc Surg 1976;72:707-8. 